\title{
The Level of Achievement for Assessment of Smart City in Smart Technology: A Literature Review
}

\author{
Hajar Hadad Sitna ${ }^{1 *}$, Arief Assaf ${ }^{1}$, and Latif Lita Asyarif ${ }^{2}$ \\ ${ }^{1}$ Smart City Islands Research Group Laboratory of Faculty of Engineering, Universitas Khairun, 97719, Ternate, Indonesia \\ ${ }^{2}$ Mechanical Department, Engineering Faculty, Khairun University, 97718, Ternate, Indonesia
}

\begin{abstract}
There are many concepts to smart cities, but in general, a smart city is a combination of the use of Information and Technology (IT) with various dimensions to increase efficiency, transparency and service quality. The dimensions of smart cities most popular are six dimensions, namely smart mobility, smart living, smart environment, smart people, smart government, and smart economy. Some literature only mentions the role of IT in the smart technology dimension but has not explained the level of achievement indicators for the smart technology dimension. The dimensions of smart technology and indicators of achievement level are carried out using a Systematic Review (SR), where more than 7.302 papers were found that match the topic and then divided into the 20 main studies based on SR protocol. The indicator of the level of achievement of the smart technology dimension in a smart city is divided into four parts, namely the use of sensors in the smart city, integration between applications (application layer), the use of technological innovations in the intelligent layer such as the IoT, big data, and cloud computing etc., and to improving the quality and scope of applications, increasing the use of AI and engagement with all public stakeholders.
\end{abstract}

Keyword: Smart City, Smart Technology, Literature Review

\section{Introduction}

In emerging age, the term smart city has become the centre of attention where in general, the smart city concept is followed by the rapid use of technology to solve city problems from various aspects [1][2]. Smart cities can be seen from various dimensions such as smart mobility, smart living, smart environment, smart people, smart government, and smart economy [3]. Because each city has unique characteristics, each city can choose the focus of smart city development according to these dimensions [4], such as China, Nanjing and Taipei focusing on the smart economy [5], Australia, Australian Capital Territory (ACT) focusing on smart people [6], as well as Spain City, the cities of Valencia and Madrid focus on implementing smart government [5].

The smart city dimensions is often used as a basic concept in assessing smart cities in various countries, such as those used by The IESE Cities in Motion Index (CIMI), Innovation City Index (ICI), The Smart Cities index, The European Digital City Index. (EDCi), Smart City Strategy Index, Global Cities Index, and Global Feasibility Survey [7]. According to Giffinger et al., according to Giffinger et al., the dimensions of smart city assessment can be divided into six dimensions, namely smart mobility, smart living, smart environment, smart people, smart government, and smart economy [3]. The six dimensions of the ITU-T Focus Group on Smart Sustainable Cities are equal to 6 dimensions of smart city Giffinger et al. but added indicators of sustainability in a smart environment [2], Maria's five dimensions, namely smart technology, smart economy, smart people, smart governance, and smart environment [7], or other dimensions that can be assessed according to the characteristics of the city. will be assessed. After the dimensions are determined, the next step before the assessment is to determine the assessment indicators for each dimension; these indicators can be in the form of achievement level [8], website address or application domain [1], and indicators set with certain criteria [6].

This research has 4 parts, namely introduction, research methodology, analysis and results as well as conclusions, where the way the author conducts a systematic review is contained in part 2 , the results of the literature analysis related to the dimensions of smart cities and the level of achievement (especially smart cities and technology) as an alternative to smart city assessments - contained in section 3, while at the end (section 4), the conclusions and future direction of the study will be presented.

Smart technology is deemed necessary to be added to the smart city dimension because ICT has an important role in smart city implementation [13] [14]

\footnotetext{
* Corresponding author : sitna.hajar00@gmail.com
} 
[1]. Some literature only mentions the role of Information and Technology (IT) in the dimension of smart technology, but has not explained the organizer level indicators for the dimension of smart technology. Therefore, in this study, the scope and indicators for the dimensions of smart technology will be determined which will be used as the basis for assessing smart cities.

\section{Research Methodology}

The approach used in this study is the methodology by Kitchenham, where the literature selected based on certain criteria will be used to answer predetermined research questions [9]. These stages are carried out as follows:

\subsection{Design Reseach Question}

The main objective of this study is to obtain all indicators of the level of achievement of each dimension of smart technology in the context of a smart city with the hope that it can be used as a basis for assessing smart cities. Design Research questions that have been identified in Table I.

Table 1. Reseach Question Design.

\begin{tabular}{|l|l|}
\hline \multicolumn{1}{|c|}{ Aspec } & \multicolumn{1}{c|}{ Explanations } \\
\hline Population & $\begin{array}{l}\text { Smart City Indicators/Dimensions/ } \\
\text { Components (not limited to certain } \\
\text { countries, regions or continents). }\end{array}$ \\
\hline Intervention & $\begin{array}{l}\text { Smart Technology Indicators/Aspects } \\
\text { ICT for Smart City, IoT for Smart City, } \\
\text { stc. }\end{array}$ \\
\hline Comparison & n/a \\
\hline Outcomes & $\begin{array}{l}\text { Indicators level achievement from all } \\
\text { dimensions of smart city (especially in the } \\
\text { dimension of smart technology) }\end{array}$ \\
\hline Context & $\begin{array}{l}\text { Konteks dalam research ini adalah dimensi } \\
\text { dan indikator level achievement smart city } \\
\text { (terutama pada dimensi smart technology). }\end{array}$ \\
\hline
\end{tabular}

\subsection{Search Process}

The literature search stage is carried out using digital libraries such as Scopus, Science Direct, IEEExplore, and SpringerLink. The keywords used to determine are in Table 2. The keywords used in this study are shown in Table 3 .

Table 2. Keyword and Search String

\begin{tabular}{|c|c|c|c|}
\hline \multicolumn{3}{|c|}{ Stage 1 } \\
\hline AND & $\boldsymbol{A N D}$ & $\boldsymbol{A N D}$ & \multirow{2}{*}{ Result } \\
\hline $\boldsymbol{O R}$ & $\boldsymbol{O R}$ & $\boldsymbol{O R}$ & \\
\hline $\begin{array}{c}\text { Level } \\
*\end{array}$ & Smart & City & \\
\cline { 1 - 2 } $\begin{array}{c}\text { Indica } \\
\text {-tor* }\end{array}$ & $\begin{array}{c}\text { Digita } \\
1^{*}\end{array}$ & Cities & \\
\hline
\end{tabular}

\begin{tabular}{|c|c|c|c|c|c|}
\hline $\begin{array}{c}\text { Phase } \\
*\end{array}$ & $\begin{array}{l}\text { Elec- } \\
\text { tronic } \\
*\end{array}$ & & & & \\
\hline Asses & e-* & & & & \\
\hline & Inov* & & & & \\
\hline \multicolumn{6}{|c|}{ Stage 2} \\
\hline$A N D$ & $A N D$ & $A N D$ & $A N D$ & \multirow{2}{*}{\multicolumn{2}{|c|}{ Result }} \\
\hline OR & OR & OR & OR & & \\
\hline $\begin{array}{l}\text { Leve } \\
1^{*}\end{array}$ & $\begin{array}{c}\text { Smar } \\
t\end{array}$ & City & $\begin{array}{l}\text { Archi- } \\
\text { tecture }\end{array}$ & \multirow{4}{*}{\multicolumn{2}{|c|}{ 2.109 Papers }} \\
\hline $\begin{array}{c}\text { Indic } \\
\text { a- } \\
\text { tor* }\end{array}$ & $\begin{array}{c}\text { Digit } \\
\mathrm{al}^{*}\end{array}$ & $\begin{array}{c}\text { Citie } \\
\mathrm{s}\end{array}$ & $\begin{array}{l}\text { Techno- } \\
\text { log** }\end{array}$ & & \\
\hline $\begin{array}{c}\text { Phas } \\
\mathrm{e}^{*}\end{array}$ & $\begin{array}{l}\text { Elec- } \\
\text { troni } \\
c^{*}\end{array}$ & & & & \\
\hline $\begin{array}{c}\text { Asse } \\
\text { ss* }\end{array}$ & e-* & & & & \\
\hline \multicolumn{6}{|c|}{ Stage 3} \\
\hline$\overline{A N D}$ & $A N D$ & $A N D$ & $A N D$ & $A N D$ & \\
\hline OR & OR & OR & OR & OR & \\
\hline $\begin{array}{l}\text { Leve } \\
1^{*}\end{array}$ & $\underset{t}{S m a r}$ & City & $\begin{array}{l}\text { Archi- } \\
\text { tecture }\end{array}$ & $\begin{array}{c}\text { Dimen- } \\
\text { sion }\end{array}$ & \multirow{4}{*}{92 Papers } \\
\hline $\begin{array}{c}\text { Indic } \\
\text { a- } \\
\text { tor* }\end{array}$ & $\begin{array}{c}\text { Digit } \\
\mathrm{al}^{*}\end{array}$ & $\begin{array}{c}\text { Citie } \\
\mathrm{s}\end{array}$ & $\begin{array}{c}\text { Techno- } \\
\text { log* }\end{array}$ & & \\
\hline $\begin{array}{c}\text { Phas } \\
\mathrm{e}^{*}\end{array}$ & $\begin{array}{l}\text { Elec- } \\
\text { troni } \\
\mathrm{c}^{*}\end{array}$ & & & & \\
\hline $\begin{array}{c}\text { Asse } \\
\text { ss* }\end{array}$ & e-* & & & & \\
\hline
\end{tabular}

Table 2 shows the stages in the search for papers, the process of filtering papers by reading the titles and abstracts of the papers and sorting based on the ranking of the relevant and most cited papers so that the papers analyzed and considered according to the topic and research questions are not limited to the papers listed in keywords. search results in stage III Table 3 . In some conditions, the literature search is not limited to the papers published above in 2016. The final selected papers used as references for this research are 20 main study papers.

\subsection{Design Criterias}

The search for papers supporting this study is limited to the criteria in Table 3.

Table 3. Inclusion and Exclusion Criteria

\begin{tabular}{|l|l|}
\hline \multicolumn{1}{|c|}{ Descriptions } & Type \\
\hline $\begin{array}{l}\text { Published research papers starting from 2016 } \\
\text { to } 2021 .\end{array}$ & Inclusion \\
\hline $\begin{array}{l}\text { Papers in the type of technical and review } \\
\text { articles. }\end{array}$ & Inclusion \\
\hline $\begin{array}{l}\text { Papers that match the smart city search string } \\
\text { and indicator level. }\end{array}$ & Inclusion \\
\hline Papers must answer the research question. & Inclusion \\
\hline
\end{tabular}




\begin{tabular}{|l|l|}
\hline Papers published before 2016 & Exclusion \\
\hline Conference papers & Exclusion \\
\hline $\begin{array}{l}\text { Subject areas that are not relevant to the } \\
\text { field of General Science (not limited to } \\
\text { computer science, social science, } \\
\text { environment science, engineering) }\end{array}$ & Exclusion \\
\hline Incomplete paper (not full text) & Exclusion \\
\hline
\end{tabular}

\section{Result and Discussion}

\subsection{The Roles of ICT in Smart City}

The concept of implementing technology in a smart city, the search for references first focuses on the definition of a smart city. Smart city is defined as the application of technology and infrastructure to improve the quality of life and sustainable resources [10]. Smart cities apply technology with the hope that the technology can solve all daily problems [11]. Smart city cannot be defined only in the context of the application of technology, but also how technology can improve economic growth, competitiveness, health, social, environment and employment opportunities [4][2].

It was found that almost all definitions of smart cities use the term technology, this shows that technology has an important role in realizing a smart city [1]. The application of technology in smart cities such as the Internet of Things, Cloud Computing and Big Data in smart cities is carried out to connect every component in all layers of the smart city [13].

To implementation a smart city, the role of not only the government but also the responsibility of all stakeholders is needed [2]. Details of the role of Information and Communication Technology (ICT) based on the definition of smart city from various literature sources as shown in Table 4.

Table 4. Technologies Roles in Smart City

\begin{tabular}{|l|l|l|}
\hline \multicolumn{1}{|c|}{ Definitions } & \multicolumn{1}{|c|}{ Key Term } & Refrerence \\
\hline $\begin{array}{l}\text { Application of technology to } \\
\text { increase economic growth, } \\
\text { health and employment. }\end{array}$ & $\begin{array}{l}\text { Technology, } \\
\text { employment, } \\
\text { health and } \\
\text { economic } \\
\text { growth, }\end{array}$ & {$[1]$} \\
\hline $\begin{array}{l}\text { Implementation of intelligent } \\
\text { technology and interactive } \\
\text { infrastructure for sustainable } \\
\text { quality of life and resource } \\
\text { improvement }\end{array}$ & $\begin{array}{l}\text { Technology, } \\
\text { infrastructure, } \\
\text { smart, } \\
\text { interactive, } \\
\text { quality of life } \\
\text { and sustainable } \\
\text { resources }\end{array}$ & {$[2]$} \\
\hline $\begin{array}{l}\text { Smart Technology used to } \\
\text { provide services to } \\
\text { stakeholders. This technology } \\
\text { draws on ambient intelligence } \\
\text { for smart energy, smart } \\
\text { mobility, and smart healthcare. }\end{array}$ & $\begin{array}{l}\text { Technology, } \\
\text { services, } \\
\text { stakeholders, } \\
\text { ambient } \\
\text { intelligence, } \\
\text { smart energy, } \\
\text { smart mobility, } \\
\text { and smart health } \\
\text { care. }\end{array}$ & {$[3]$} \\
\hline $\begin{array}{l}\text { The application of technology } \\
\text { to solve all existing everyday } \\
\text { problems. }\end{array}$ & $\begin{array}{l}\text { Technology, } \\
\text { everyday }\end{array}$ & {$[4]$} \\
\hline
\end{tabular}

\begin{tabular}{|l|l|l|}
\hline & $\begin{array}{l}\text { problems, } \\
\text { society. }\end{array}$ & \\
\hline $\begin{array}{l}\text { Application of technology for } \\
\text { socio-economic, } \\
\text { environmental, and city/local } \\
\text { operational aspects. }\end{array}$ & $\begin{array}{l}\text { Technology, } \\
\text { socio-economics, } \\
\text { environment, and } \\
\text { city logistics. }\end{array}$ & {$[5]$} \\
\hline $\begin{array}{l}\text { The implementation of } \\
\text { technology in line with policies } \\
\text { and strategies for } \\
\text { implementing technology and } \\
\text { infrastructure in the country. }\end{array}$ & $\begin{array}{l}\text { Technology, } \\
\text { policy, strategy, } \\
\text { implementation, } \\
\text { and } \\
\text { infrastructure. }\end{array}$ & {$[6]$} \\
\hline $\begin{array}{l}\text { Implementation of Information } \\
\text { and Communication } \\
\text { Technology to improve } \\
\text { services, especially integration } \\
\text { with all domains. }\end{array}$ & $\begin{array}{l}\text { Technology, } \\
\text { information, } \\
\text { communication, } \\
\text { service, } \\
\text { integration. }\end{array}$ & {$[7]$} \\
\hline
\end{tabular}

\subsection{The Roles of Smart Technologies in Smart City}

Knowing the role of ICT in a smart city, an analysis was carried out with a literature review to determine the dimensions of smart technology in the smart city context. The most popular or most frequently used smart city dimensions are the 6 dimensions of Giffinger et al (smart mobility, smart living, smart environment, smart people, smart government, and smart economy) [3] with smart technology one of the dimensions of the smart city from various other literature perspectives. dimensions of smart technology can be seen in Table 6 .

Table 5. Deskripsi dimensi smart technology

\begin{tabular}{|c|c|c|}
\hline Dimensi & Components & $\begin{array}{c}\text { Referenc } \\
\text { es }\end{array}$ \\
\hline \multirow{3}{*}{$\begin{array}{l}\text { Smart } \\
\text { technology }\end{array}$} & $\begin{array}{l}\text { - The use of smart computing for } \\
\text { government services. } \\
\text { - The use of renewable technologies } \\
\text { such as internet of things, big data, } \\
\text { sensing, and business intelligent. } \\
\text { - Service and technology } \\
\text { interconnection. } \\
\text { - System integration. } \\
\text { - Focus on data. } \\
\text { - The use of architectures such as } \\
\text { cloud computing, fog computing } \\
\text { and edge computing. } \\
\text { - Provision of electronic-based } \\
\text { applications for government } \\
\text { services (Government to } \\
\text { Government (G2G), Government } \\
\text { to Business (G2B), Government to } \\
\text { Citizen (G2C), and Government to } \\
\text { Employee (G2E)). }\end{array}$ & {$[8]$} \\
\hline & $\begin{array}{l}\text { - Integration of technology and } \\
\text { architecture. } \\
\text { - increased information security and } \\
\text { data privacy. } \\
\text { - Data exchange, big data. } \\
\text { - Improve cyber security and data } \\
\text { privacy. } \\
\text { - Data processing. } \\
\text { - Data storage. } \\
\text { - Technologies for smart cities } \\
\text { (Internet of Thing, Sensing, smart } \\
\text { grid). }\end{array}$ & {$[2]$} \\
\hline & $\begin{array}{l}\text { - Technology and infrastructure } \\
\text { investment. } \\
\text { - Integrated technology. } \\
\text { - Security information. } \\
\text { - Digital administration and } \\
\text { services. } \\
\text { - Mobile and web technology. }\end{array}$ & {$[6]$} \\
\hline
\end{tabular}




\begin{tabular}{|c|c|}
\hline $\begin{array}{l}\text { - Data storage, processing and } \\
\text { visualization. } \\
\text { - Strengthening the network or ICT } \\
\text { network. }\end{array}$ & \\
\hline $\begin{array}{l}\text { - Use of renewable technologies } \\
\text { such as Internet of Thing, Big } \\
\text { Data, Sensing, and Business } \\
\text { intelligent. } \\
\text { - Use of cloud computing. } \\
\text { - Use of artificial intelligence } \\
\end{array}$ & [5] \\
\hline $\begin{array}{l}\text { - Use of smart box mesh netwok. } \\
\text { - Use of software architecture. } \\
\text { - Use of Data collecting, storage, } \\
\text { and decision making. } \\
\text { - Use of wireless communication } \\
\text { technology. }\end{array}$ & [9] \\
\hline
\end{tabular}

The relationship smart technology based on Table 5 and Table 6 , the dimensions of the smart city can be explained in Table 7.

Table 6. Deskripsi dimensi smart city based[Griffger]

\begin{tabular}{|l|l|}
\hline Dimensions & Descriptions \\
\hline $\begin{array}{l}\text { Smart } \\
\text { Mobility }\end{array}$ & $\begin{array}{l}\text { Leads to creation smart transportation } \\
\text { teknologi seperti smart route, smart vehicle, } \\
\text { smart traffic management and smart alert } \\
\text { driving system. }\end{array}$ \\
\hline $\begin{array}{l}\text { Smart } \\
\text { Living }\end{array}$ & $\begin{array}{l}\text { Leads to improving the quality of life such as } \\
\text { smart home, smart health, smart education, } \\
\text { smart culture atau tourism, dan public safety. }\end{array}$ \\
\hline Smart & $\begin{array}{l}\text { Leads to environmental efficiency such as } \\
\text { resource management, maintaining green open } \\
\text { spaces, use of renewable energy, green and } \\
\text { clean energy, emission control, pollution, air } \\
\text { quality, and water quality. }\end{array}$ \\
\hline $\begin{array}{l}\text { Smart } \\
\text { People }\end{array}$ & $\begin{array}{l}\text { Leading to community involvement for } \\
\text { government services, data privacy, as well as } \\
\text { increasing expertise, skills, intelligence, } \\
\text { creativity, and technology adaptation in society. }\end{array}$ \\
\hline Smart & $\begin{array}{l}\text { Leads to the provision of government services, } \\
\text { openness, transparency and accountability of } \\
\text { data, information between departments, } \\
\text { communities, and businesses. }\end{array}$ \\
\hline $\begin{array}{l}\text { Smart } \\
\text { Economy }\end{array}$ & $\begin{array}{l}\text { Leads to supporting local businesses to increase } \\
\text { productivity, competition and global markets. }\end{array}$ \\
\hline Technology & $\begin{array}{l}\text { Leads to the use of renewable technology and } \\
\text { infrastructure, system integration, focus on data } \\
\text { development, artificial intelligence and } \\
\text { provision of electronic-based government } \\
\text { applications. }\end{array}$ \\
\hline
\end{tabular}

The main dimensions of a smart city, such as smart technology [10] [7] [1] [2] [11] [12] [17] are important to add considering that the basic component of a smart city is technology as the results of the literature review determine the role of ICT based on the definition of smart. city in table 5. The technology in question is not the main component of a smart city, but is a basic component for implementing all components/dimensions in a smart city [12], therefore in this study the dimensions of smart technology will be added.

\subsection{The Level Achievement Indicators in Smart Technology}

To implementing a smart city, indicators are needed to assess whether the goals of smart city development have been achieved from all aspects that have been set [19]. These assessment indicators may vary as shown in Table 7.
Table 7. Assessment Smart City Indicators

\begin{tabular}{|c|c|}
\hline Indicators & $\operatorname{Ref}$ \\
\hline $\begin{array}{l}\text { Using } 4 \text { levels of achievement indicators with basic, } \\
\text { medium, advanced, and state of the art levels in } \\
\text { every dimension of the smart city (smart mobility, } \\
\text { smart living, smart environment, smart people, smart } \\
\text { government, and smart economy). }\end{array}$ & [10] \\
\hline $\begin{array}{l}\text { Using } 5 \text { levels of maturity indicators for each } \\
\text { dimension of smart city (smart mobility, smart } \\
\text { living, smart environment, smart people, smart } \\
\text { government, and smart economy) with details: } \\
\text { Level 1: Smart city implementation }<10 \% \text {, where } \\
\text { there is no system to support services. } \\
\text { Level 2: Implementation } 10 \%<x<40 \% \text {, where ICT } \\
\text { integration is limited and the concept of a smart city } \\
\text { implementation strategy is found. } \\
\text { Level 3: Implementation } 40 \%<x<=70 \% \text {, where the } \\
\text { smart city basis has been implemented, ICT } \\
\text { integration, and smart city goals are documented. } \\
\text { Level 4: Implementation of } 70 \%<x<=90 \% \text {, where } \\
\text { the results of Strategic Plan } 1 \text { can be measured, } \\
\text { documentation is clear, evaluation } \\
\text { implementation is carried out, and continuous } \\
\text { improvement is carried out by learning or adopting } \\
\text { from other cities, stakeholders, and best practice } \\
\text { cases. } \\
\text { Level 5: Implementation }>90 \% \text {, where continuous } \\
\text { planning is carried out with real time data, the use of } \\
\text { artificial intelligence, and integration with all } \\
\text { stakeholders. The city focuses on sustainability that } \\
\text { prioritizes quality measurement and improvement. }\end{array}$ & [11] \\
\hline $\begin{array}{l}\text { The indicator value is from } 1-100 \text { with certain } \\
\text { dimensions of the smart city, where the number } 100 \\
\text { is the ideal smart city condition. }\end{array}$ & [6] \\
\hline $\begin{array}{l}\text { Using indicators that represent } 26 \text { factors in each } \\
\text { dimension of a smart city (smart mobility, smart } \\
\text { living, smart environment, smart people, smart } \\
\text { government, and smart economy). }\end{array}$ & [12] \\
\hline $\begin{array}{l}\text { Using } 3 \text { main work areas in each dimension of the } \\
\text { smart city (smart mobility, smart living, smart } \\
\text { environment, smart people, smart government, and } \\
\text { smart economy). }\end{array}$ & [13] \\
\hline
\end{tabular}

In this study, the indicator level will be divided into 4 parts as the concept of Y. Mohd Adnan et al refers to Table 9. The indicator level of each smartcity dimension is divided into 4 parts where level I represents the basic level, level II represents the intermediate level, level III represents the advanced level, and level IV states the level of state of the art. The use of the concept of Y. Mohd Adnan et al in this study was carried out because the concept presented by Y. Mohd Adnan et al is a simple concept modified from the Giffinger concept with leaner data (mainly using qualitative data and heuristic concepts). In addition, the application of the concept of indicators of the level of achievement of smart cities by Y. Mohd Adnan et al. has been carried out in the cities of Iskandar Malaysia, Singapore, and Seoul, where the characteristics of the city resemble other cities in Asia Pacific such as cities in Indonesia. The details of each indicator of the level of achievement of the smart city as a concept by Y. Mohd Adnan et al can be seen in Table 8 . 
Table 8. The level achievement smart technology

\begin{tabular}{|l|c|l|}
\hline Dimensions & Level & \multicolumn{1}{|c|}{ Description } \\
\hline $\begin{array}{l}\text { Smart } \\
\text { Technology }\end{array}$ & Level 1 & $\begin{array}{l}\text { The use of layer sensors in smart } \\
\text { cities[14][15]. }\end{array}$ \\
\cline { 2 - 3 } & Level 2 & $\begin{array}{l}\text { Integration between applications } \\
{[14][15] .}\end{array}$ \\
\cline { 2 - 4 } & Level 3 & $\begin{array}{l}\text { The use of renewable technology at } \\
\text { the intelligent layer such as internet of } \\
\text { things, big data, cloud computing } \\
\text { services and intelligent grid[14][15]. }\end{array}$ \\
\cline { 2 - 4 } & Level 4 & $\begin{array}{l}\text { Improving the quality and scope of } \\
\text { applications, increasing the use of } \\
\text { artificial intelligence and } \\
\text { accommodating citizen feedback } \\
\text { (citizen centric) as well as all } \\
\text { stakeholders who use the } \\
\text { system[[15][14]. }\end{array}$ \\
\hline
\end{tabular}

Table 8 Showed the indicators for the level of achievement of smart cities listed in Table 10 do not show smart technology as one of the dimensions of a smart city. Indicators of the level of achievement of smart cities for the dimensions of smart technology are also determined by the concept approach of Y. Mohd Adnan et al which is carried out heuristically based on the smart city roadmap and industrial development 4.0.

\section{Conglusion and Future Work}

The concept and definition of a smart city from various sources is very diverse, but it can be concluded that a smart city is the use of smart and integrated technology and infrastructure to solve everyday problems and improve the quality of life in a sustainable manner. Given the very large role of technology in smart cities, the dimensions of smart technology were added to the smart city which previously referred to the 6 dimensions by Giffinger [Reff].

The dimensions of the smart city are analyzed in terms of the scope and indicators of the level of achievement by using a heuristic approach as the concept of indicators of the level of achievement of the smart city by Y. Mohd Adnan et al [Ref]. In determining the scope and indicators of the level of achievement of a smart city, the research also focuses on determining the scope of dimensions and indicators of the level of achievement of smart technology. The phase or level that occurs in smart technology starts from the use of sensing technology, then continues with integration between applications and the use of smart and innovative technology to support the creation of a smart city. The last stage or the highest level of smart technology is the evaluation and continuous improvement of the applications and technologies used by involving all stakeholders and focusing on the needs of stakeholders.

For future work, the study aims to introduce the concept of Y. Mohd Adnan et al, where the concept of determining the level of smart city assessment indicators is carried out using a heuristic approach by modifying the Giffinger concept for smart city assessment by adding dimensions to the smart city with the dimensions of smart technology. The approach to determining the indicator level of the smart city assessment with other concepts such as a quantitative approach with more complex indicator data.

Authors say thanks to Dean and Staff of Faculty of Engineering, Universitas Khairun, Ternate, special work by Smart Islands Research Group Laboratory for this pilot Project Research in Northern Maluku.

\section{References}

1. Glasmeier, A.; Christopherson, S. Thinking about smart cities. Cambridge J. Reg. Econ. Soc. (2015), 8, 3-12, doi:10.1093/cjres/rsu034.

2. Ismagilova, E.; Hughes, L.; Dwivedi, Y.K.; Raman, K.R. Smart cities: Advances in research-An information systems perspective. Int. J. Inf. Manage. (2019), 47, 88-100, doi:10.1016/j.ijinfomgt.2019.01.004.

3. Ohtsuki, T. A smart city based on ambient intelligence. IEICE Trans. Commun. (2017), E100B, 1547-1553, doi:10.1587/transcom.2016PFI0012.

4. Kummitha, R.K.R.; Crutzen, N. How do we understand smart cities? An evolutionary perspective. Cities (2017), 67, 43-52, doi:10.1016/j.cities.2017.04.010.

5. Winkowska, J.; Szpilko, D.; Pejić, S. Smart city concept in the light of the literature review. Eng. Manag. Prod. Serv. (2019), 11, 70-86, doi:10.2478/emj-2019-0012.

6. Alderete, M.V. Exploring the Smart City Indexes and the Role of Macro Factors for Measuring Cities Smartness. Soc. Indic. Res. (2020), 147, 567-589, doi:10.1007/s11205-019-02168-y.

7. Weingart, L.R.; Thompson, L.L.; Bazerman, M.H.; Carroll, J.S. ICT and sustainability in smart cities management. Int. J. Public Sect. Manag. (2016), 29, 132-147, doi:https://doi.org/10.1108/IJPSM-072015-0132.

8. Sánchez-Corcuera, R.; Nuñez-Marcos, A.; SesmaSolance, J.; Bilbao-Jayo, A.; Mulero, R.; Zulaika, U.; Azkune, G.; Almeida, A. Smart cities survey: Technologies, application domains and challenges for the cities of the future. Int. J. Distrib. Sens. Networks (2019), doi:10.1177/1550147719853984.

9. Soyata, T.; Habibzadeh, H.; Ekenna, C.; Nussbaum, B.; Lozano, J. Smart city in crisis: Technology and policy concerns. Sustain. Cities Soc. (2019), 50, 101566, doi:10.1016/j.scs.2019.101566.

10. Mohd Adnan, Y.; Hamzah, H.; Md Dali, M.; Nasir Daud, M.; Anuar Alias An initiatives-based framework for assessing smart city. Plan. Malaysiacity Rank. Eur. Mediu. sized (2016), 13-22, doi:10.21837/pmjournal.v14.i5.189.

11. Warnecke, D.; Wittstock, R.; Teuteberg, F. Benchmarking of European smart cities - a maturity model and web-based self-assessment tool. Sustain. Accounting, Manag. Policy J. (2019), 10, 654-684, doi:10.1108/SAMPJ-03-2018-0057.

12. Ur Rehman Tariq, M.A.; Faumatu, A.; Hussein, M.; Ur Rahman Shahid, M.L.; Muttil, N. Smart cityranking of major australian cities to achieve a 
smarter future. Sustain. (2020), 12, 1-19, doi:10.3390/su12072797.

13. Calderon, M.; Lopez, G.; Marin, G. Smartness and technical readiness of Latin American Cities: A critical assessment. IEEE Access (2018), 6, 5683956850, doi:10.1109/ACCESS.2018.2864218.

14. Lu, H.P.; Chen, C.S.; Yu, H. Technology roadmap for building a smart city: An exploring study on methodology. Futur. Gener. Comput. Syst. (2019), 97, 727-742, doi:10.1016/j.future.2019.03.014.

15. Oztemel, E.; Gursev, S. Literature review of Industry 4.0 and related technologies. J. Intell. Manuf. (2020), 31, 127-182, doi:10.1007/s10845018-1433-8. 